\title{
THE EFFECTS OF CHEMICAL WEED CONTROL ON QUALITY OF TRANSPLANTS PRODUCED IN THE PLASTIC TUNNEL AND FINAL YIELD OF LEEKS
}

\author{
Katarzyna ADAMCZEWSKA-SOWIŃSKA, Eugeniusz KOŁOTA \\ Department of Horticulture \\ Wroclaw University of Environmental and Life Sciences \\ pl. Grunwaldzki 24 a, 50-363 Wrocław, Poland
}

Received: April 6, 2009; Accepted: July 12, 2009

\begin{abstract}
Summary
In 2006-2008 there was conducted a study to determine the suitability of pendimethalin (Stomp $330 \mathrm{EC}$ ), glyphosate (Roundup $360 \mathrm{SL}$ ) and mixture of propachlor and glyphosate (Ramrod Flo 480 SC and Roundup 360 SL) as pre emergence herbicides in leek seedlings raising, and supplementary use of propachlor at the flag stage. The subject of evaluation was the efficiency of weed control, quality of transplants and finally the yield of leeks.

Results of the study indicate that the efficient method of weed control during seedlings raising of leek was pre emergence use of pendimethalin at the rate of $990 \mathrm{~g} \cdot \mathrm{ha}^{-1}$ after seed sowing or mixture of propachlor $\left(3840 \mathrm{~g} \cdot \mathrm{ha}^{-1}\right)$ and glyphosate $\left(720 \mathrm{~g} \cdot \mathrm{ha}^{-1}\right)$ before seed emergence. Supplementary application of propachlor at the flag stage slightly increased the efficiency of chemical weed control but did not influence on the quality of transplants and yield of the crop.

Chemical weed control did not adversely affect on the quality of seedling and yield of leek, except glyphosate which efficiency in weed control was not satisfactory. Heavy weed infestation during seedlings production diminished the quality parameters of transplants and yield of leek by $34.3 \%$.
\end{abstract}

key word: leek, chemical weed control, transplant quality, marketable yield

\section{INTRODUCTION}

Leeks can be grown as direct drilling or transplanted crops. Direct sowing into open field in the spring is cheaper method than transplanting but provides plants with shorter length of blended pseudostems and more prone to bulbiness.

Actually most of the leeks supplied to the market are being grown from transplants. Different systems of seedlings production are used in the practice, including bare root transplants, peat blocks, plastic pots or rings and recently multiseeded trays containing different amounts of medium but not less than

Corresponding author:

e-mail: katarzyna.a-sowinska@up.wroc.pl

(C) Copyright by RIVC 
$15 \mathrm{ml}$ per cell (Kołota \& Adamczewska-Sowińska 1995, Fritz et al. 1989, Le Bohec et al. 1993, Brewster 2008).

The seedling raising in pots with supplemental lighting during the period of 5 weeks after emergence is recognized as the most suitable for early harvest in June or July (Kołota \& Adamczewska-Sowińska 1996). Leeks grown for late harvest during autumn or after overwintering in the field are mostly grown from bare root transplants produced in the plastic tunnels or in the seedbed. Yield and mean plant weights at harvest correlate well with mean weight at transplanting (Krug \& Kling 1978, Brewster \& Steckel 1989, Synnevag \& Stubhang 1990). Maync (1990) suggests using the well hardened transplants with a mean weight over $2 \mathrm{~g}$ while Krug (1986) found the best yielding crop from seedlings with a weight exceeding $4 \mathrm{~g}$ and in the case of late planting combined with sprinkler irrigation $-8 \mathrm{~g}$.

Seedlings of this species are growing slowly, so plant raising usually takes 8-12 weeks, depending on light and temperature. In our study (Adamczewska-Sowińska \& Kołota 2005) it was proved that sowing $2 \mathrm{~g}$ of seeds per $1 \mathrm{~m}^{2}$ of seedbed and prolonged to 12 weeks period of transplant production assured the best quality of transplants and the highest yield of leeks.

Leek belongs to the group of vegetable species with a high susceptability to weed infestation (Dobrzański 1998) and critical period of weed competition lasts since seed emergence till the stage of 2-3 true leaves. For this reason an efficient method of weed control in seed bed is required to receive high quality of transplants. The most efficient and low labour demand method of weed control is the use of herbicides. Leek needs a similar herbicide programme as onion but it is some more sensitive to postemergence treatment due to run off of liquids (Grundy et al. 2003).

For leeks grown from direct drilling into the field there are recommended such chemicals as propachlor, pendimethalin, linuron and glyphosate, but till now there are not indications for their use during seedlings production. The aim of the experiment was to compare the effects of some herbicides applied preand postemergence on weed control, quality of transplants produced in plastic tunnel and final yield of leeks grown for autumn harvest.

\section{MATERIAL AND METHODS}

The experiment was conducted in 2006-2008 at Horticultural Experimental Station belonging to the Wrocław University of Environmental and Life Sciences. Transplants of leeks cv. Shelton $\mathrm{F}_{1}$ were produced in high plastic tunnel from sowing on $10^{\text {th }}$. April, at the rate of $2 \mathrm{~g}$ seeds per $1 \mathrm{~m}^{2}$ with $10 \mathrm{~cm}$ row spacing. The following herbicide treatments were included in the study:

1. pendimethalin (Stomp 330 EC) $990 \mathrm{~g} \cdot \mathrm{ha}^{-1}$ applied 3 days after seeding,

2. glyphosate (Roundup $360 \mathrm{SL}$ ) $720 \mathrm{~g} \cdot \mathrm{ha}^{-1}$, applied 3 days before seed emergence,

3. propachlor (Ramrod Flo 480 SC) $3840 \mathrm{~g} \cdot \mathrm{ha}^{-1}+$ glyphosate (Roundup 360 SL) $720 \mathrm{~g} \cdot \mathrm{ha}^{-1}$, applied 3 days before seed emergence, 
4. pendimethalin (Stomp $330 \mathrm{EC}$ ) $990 \mathrm{~g} \cdot \mathrm{ha}^{-1}$, applied 3 days after seeding propachlor (Ramrod Flo $480 \mathrm{SC}) 5280 \mathrm{~g} \cdot \mathrm{ha}^{-1}$, applied at the flag stage

5. glyphosate (Roundup $360 \mathrm{SL}) 720 \mathrm{~g} \cdot \mathrm{ha}^{-1}$, applied 3 days before seed emergence

propachlor (Ramrod Flo $480 \mathrm{SC}$ ) $5280 \mathrm{~g} \cdot \mathrm{ha}^{-1}$, applied at the flag stage,

6. propachlor (Ramrod Flo $480 \mathrm{SC}) 3840 \mathrm{~g} \cdot \mathrm{ha}^{-1}+$ glyphosate (Roundup360

SL) $720 \mathrm{~g} \cdot \mathrm{ha}^{-1}$, applied 3 days before seed emergence

propachlor (Ramrod Flo $480 \mathrm{SC}$ ) $5280 \mathrm{~g} \cdot \mathrm{ha}^{-1}$, applied at the flag stage,

7. unweeded control,

8. hand weeded control.

Weed infestation, including the number, weight of fresh biomass and degree of soil cover by weeds was evaluated on $10^{\text {th }}$ of May in treatments 1-3, and on $17^{\text {th }}$ of June in all treatments of the study. Quality of transplants expressed by mean weight of plant, bulb diameter, height and number of leaves per plant was determined on $20^{\text {th }}$ of June, directly before leek transplanting.

Well hardened bare root transplants were used for evaluation of leek yield in the field experiment, conducted on a fine clay soil with $1.8 \%$ organic matter and $\mathrm{pH}$ 6.9. Available forms of phosphorus and potassium were raised up by early spring fertilization to the standard level $60 \mathrm{mg} \mathrm{P}$ and $200 \mathrm{mg} \mathrm{K}$ per $1 \mathrm{dm}^{3}$ of the soil. Nitrogen was applied at the rate of $100 \mathrm{~kg} \mathrm{~N} \cdot \mathrm{ha}^{-1}$ as the preplant dose and $50 \mathrm{~kg} \mathrm{~N} \cdot \mathrm{ha}^{-1}$ as top dressing in the middle of July.

Seedlings from all herbicide treatments were planted on $21^{\text {st }}$ of June in spacing $40 \times 20 \mathrm{~cm}$. Plants were trimmed and graded to class I with bulb diameter $>2.5 \mathrm{~cm}$, and class II with $1.5-2.5 \mathrm{~cm}$ during harvesting on $6^{\text {th }}-8^{\text {th }}$ of November.

Both studies conducted in the plastic tunnel and in the open field were arranged in one factorial design in four replications. The area of the plot for seedlings raising was $2 \mathrm{~m}^{2}$ and in the field trials $-12 \mathrm{~m}^{2}(3 \times 4 \mathrm{~m})$. The data concerning yield were analised by standard statistical procedure, and the least significant differences calculated by Tukey's test at $\mathrm{P}=0.05$.

\section{RESULTS AND DISCUSSION}

Results of the study shown in Table 1, as three years means indicate that in both terms of evaluation the dominated weed species on plots during transplant raising was Chenopodium album L., which degree of infestation amounted $43 \%$ and $25.4 \%$, respectively. The other major weeds found were Echinochloa crus galli L. (14 and 18.2\%) Amaranthus retroflexus L. (12 and 5.0\%), Galinsoga parviflora Cav. (7.2 and 14\%). Among pre emergence herbicide treatments the best weed control one month after seed sowing and at the end of seedling raising was assured by pendimethalin application at the rate of 990 $\mathrm{g} \cdot \mathrm{ha}^{-1}$. Similar effects for the number of weeds present on the plots, their biomass and degree of soil coverage were observed in treatment with combined use of propachlor $\left(3840 \mathrm{~g} \cdot \mathrm{ha}^{-1}\right)$ and glyphosate $\left(720 \mathrm{~g} \cdot \mathrm{ha}^{-1}\right)$. Considerably higher 
weed infestation was found in the case of glyphosate $\left(720 \mathrm{~g} \cdot \mathrm{ha}^{-1}\right)$, use in the term of 3 days before seed emergence.

Supplemental propachlor application at the rate of $5280 \mathrm{~g} \cdot \mathrm{ha}^{-1}$ at the flag stage of leek seedlings slightly increased the weed control effects of pre emergence herbicide treatments only. Its efficiency was most pronounced in the case of post sowing use of combined herbicides propachlor and glyphosate.

Table 1. Evaluation of weed infestation in leek transplants production (mean from 20062008)

\begin{tabular}{|c|c|c|c|c|c|c|c|}
\hline \multirow[b]{2}{*}{$\begin{array}{c}\text { Herbicide } \\
\text { and term } \\
\text { of application }\end{array}$} & \multirow[b]{2}{*}{$\begin{array}{l}\text { Rate of } \\
\text { active } \\
\text { ingre- } \\
\text { dients } \\
\left(\mathrm{g} \cdot \mathrm{ha}^{-1}\right)\end{array}$} & \multicolumn{3}{|c|}{10.05 . } & \multicolumn{3}{|c|}{17.06.} \\
\hline & & $\begin{array}{l}\text { Degree } \\
\text { of soil } \\
\text { cover by } \\
\text { weeds } \\
(\%)\end{array}$ & $\begin{array}{l}\text { Number } \\
\text { of weeds } \\
\text { per } 1 \mathrm{~m}^{2}\end{array}$ & $\begin{array}{l}\text { Weight } \\
\text { of } \\
\text { weeds } \\
\left(\mathrm{g} \cdot \mathrm{m}^{-2}\right)\end{array}$ & $\begin{array}{l}\text { Degree } \\
\text { of soil } \\
\text { cover by } \\
\text { weeds } \\
(\%)\end{array}$ & $\begin{array}{l}\text { Number } \\
\text { of weeds } \\
\text { per } 1 \mathrm{~m}^{2}\end{array}$ & $\begin{array}{l}\text { Weight } \\
\text { of } \\
\text { weeds } \\
\left(\mathrm{g} \cdot \mathrm{m}^{-2}\right)\end{array}$ \\
\hline $\begin{array}{l}\text { pendimethalin } \\
-3 \text { days affter } \\
\text { seeding }\end{array}$ & 990 & 6.0 & 91.5 & 34.1 & 23.0 & 35.3 & 169.8 \\
\hline $\begin{array}{l}\text { glyphosate } \\
-3 \text { days before } \\
\text { leek emergence }\end{array}$ & 720 & 36.0 & 177.8 & 71.1 & 56.0 & 136.0 & 340.0 \\
\hline $\begin{array}{l}\text { propachlor }+ \\
\text { glyphosate } \\
-3 \text { days before } \\
\text { leek emergence }\end{array}$ & $3840+720$ & 9.0 & 66.7 & 22.5 & 60.0 & 43.2 & 177.1 \\
\hline $\begin{array}{l}\text { pendimethalin } \\
\text { - } 3 \text { days affter } \\
\text { seeding pro- } \\
\text { pachlor } \\
\text { - at flag stage } \\
\end{array}$ & 5280 & & & & 64.0 & 25.0 & 124.4 \\
\hline $\begin{array}{l}\text { glyphosate } \\
-3 \text { days before } \\
\text { leek emergence } \\
\text { propachlor } \\
\text { - at flag stage }\end{array}$ & 5280 & & & & 75.0 & 120.6 & 240.0 \\
\hline $\begin{array}{l}\text { propachlor }+ \\
\text { glyphosate } \\
-3 \text { days before } \\
\text { leek emergence } \\
\text { propachlor } \\
\text { - at flag stage }\end{array}$ & $3840+720$ & & & & 15.0 & 20.0 & 112.2 \\
\hline unweeded control & & 100.0 & 326.9 & 362.7 & 100.0 & 173.8 & 2198.7 \\
\hline
\end{tabular}

The best quality seedlings at planting, expressed by mean weight of plant, recognized as the most important quality parameter, as well as bulb diameter, height of plant and number of leaves was obtained in hand weeded control (Table 2). Results of the study confirmed the statement of Dobrzański (1998) indicating leek as very sensitive species to weed competition due to its slow emergence and initial growth. In unweeded control the mean weight of transplants was reduced from $10.5 \mathrm{~g}$ to $1.5 \mathrm{~g}$, bulb diameter from $5.7 \mathrm{~mm}$ do $2.4 \mathrm{~mm}$ and 
number of leaves from 4.7 to 3 . Such the high negative effects of weeds present during seedlings raising can be explained by heavy infestations of experimental field by Chenopodium album L. which is being considered as a very strong competitor for such crops as leek or onion (Dobrzański et al. 2002).

High quality parameters of seedlings were obtained on plots with chemical weed control by pendimethalin used 3 days after seed drilling or mixture of propachlor and glyphosate in 3 days before seed emergence. Supplementary application of propachlor at the flag stage had only slights beneficial effect on seedling quality in treatment with pre emergence use of propachlor and glyphosate mixture.

Table 2. Quality of leek seedlings at transplanting (mean from 2006-2008)

\begin{tabular}{|c|c|c|c|c|c|}
\hline $\begin{array}{l}\text { Herbicide and term } \\
\text { of application }\end{array}$ & $\begin{array}{l}\text { Rate of } \\
\text { active in- } \\
\text { gredients } \\
\left(\mathrm{g} \cdot \mathrm{ha} \mathrm{a}^{-1}\right)\end{array}$ & $\begin{array}{l}\text { Weight } \\
\text { of plant } \\
\quad(\mathrm{g})\end{array}$ & $\begin{array}{l}\text { Bulb } \\
\text { diameter } \\
(\mathrm{mm})\end{array}$ & $\begin{array}{l}\text { Plant } \\
\text { height } \\
(\mathrm{cm})\end{array}$ & $\begin{array}{l}\text { Number } \\
\text { of leaves } \\
\text { per plant }\end{array}$ \\
\hline $\begin{array}{l}\text { pendimethalin - } 3 \text { days } \\
\text { after seeding }\end{array}$ & 990 & 8.3 & 5.4 & 49.2 & 4 \\
\hline $\begin{array}{l}\text { glyphosate - } 3 \text { days before } \\
\text { leek emergence }\end{array}$ & 720 & 5.9 & 4.1 & 45.6 & 3.6 \\
\hline $\begin{array}{l}\text { propachlor + glyphosate } \\
\text { - } 3 \text { days before leek emer- } \\
\text { gence }\end{array}$ & $3840+720$ & 7.5 & 4.9 & 48 & 4.1 \\
\hline $\begin{array}{l}\text { pendimethalin - } 3 \text { days } \\
\text { after seeding } \\
\text { propachlor - at flag stage }\end{array}$ & $\begin{array}{r}990 \\
5280 \\
\end{array}$ & 5.7 & 4.3 & 50.9 & 3.9 \\
\hline $\begin{array}{l}\text { glyphosate - } 3 \text { days before } \\
\text { leek emergence } \\
\text { propachlor - at flag stage }\end{array}$ & $\begin{array}{r}720 \\
5280\end{array}$ & 4 & 3.8 & 44 & 3.8 \\
\hline $\begin{array}{l}\text { propachlor+ glyphosate } \\
\text { - } 3 \text { days before leek emer- } \\
\text { gence } \\
\text { propachlor - at flag stage }\end{array}$ & $3840+720$ & 8.3 & 5.3 & 47.7 & 4.4 \\
\hline hand weeded control & & 10.5 & 5.7 & 54.6 & 4.7 \\
\hline unweeded control & & 1.5 & 2.4 & 43.8 & 3 \\
\hline
\end{tabular}

Results of the field study shown as means from three years (Table 3) proved close relationship between quality of seedlings used for planting and marketable yield of leeks, what is compliance with our previous research data (Kołota \& Adamczewska-Sowińska 1995, Adamczewska-Sowińska \& Kołota 2005) and the results presented by Krug \& Kling (1978). The best quality transplants received in hand weeded control assured the marketable yield of leeks equal to $33.51 \mathrm{t} \cdot \mathrm{ha}^{-1}$, and mean weight of plant amounted $288.3 \mathrm{~g}$. However, not significant differences were found between this treatment and the others with chemical weed control of leeks during seedlings raising. The only exception was glyphosate, which was not enough effective in weed control and as a result 
of low quality of produced transplants significantly decreased the yield of leeks. Poor quality seedlings obtained on non weeded plots resulted in reduction of marketable yield by $34.3 \%$ as compared to the hand weeded seedlings. The mean weight of plant in marketable yield in this treatment was also significantly lower than in the case of using high quality transplants received from weed free plots. Similar relations between transplant parameters and mean weight of plant at harvest were observed by Benjamin (1984) who compared the seedlings graded into large, medium and small. At the later on 221 days harvest the corresponding mean plant weight were amounted 299, 261 and $217 \mathrm{~g}$. The author concluded that in order to compensate late leek planting in July, there is necessary to use well developed seedlings at least 5-6 $\mathrm{mm}$ in diameter.

Table 3. Marketable yield of leek in relation to the method of weed control during seedling production (mean from 2006-2008)

\begin{tabular}{|c|c|c|c|c|}
\hline $\begin{array}{l}\text { Herbicide and method } \\
\text { of application }\end{array}$ & $\begin{array}{l}\text { Rate of } \\
\text { active in- } \\
\text { gredients } \\
\left(\mathrm{g} \cdot \mathrm{ha}^{-1}\right)\end{array}$ & $\begin{array}{l}\text { Marketable } \\
\text { yield } \\
\left(\mathrm{t} \cdot \mathrm{ha}^{-1}\right)\end{array}$ & $\begin{array}{c}\text { Percentage of } \\
\text { plants with } \\
\text { bulb diameter } \\
>2.5 \mathrm{~cm} \\
\text { in marketable } \\
\text { yield }\end{array}$ & $\begin{array}{l}\text { Weight } \\
\text { of plant } \\
\text { (g) }\end{array}$ \\
\hline $\begin{array}{l}\text { pendimethalin - days after } \\
\text { seeding }\end{array}$ & 990 & 28.54 & 77.9 & 265.7 \\
\hline $\begin{array}{l}\text { glyphosate - } 3 \text { days before leek } \\
\text { emergence }\end{array}$ & 720 & 26.99 & 78.1 & 253.3 \\
\hline $\begin{array}{l}\text { propachlor }+ \text { glyphosate } \\
-3 \text { days before leek emergence }\end{array}$ & $3840+720$ & 31.76 & 78.1 & 290.6 \\
\hline $\begin{array}{l}\text { pendimethalin - } 3 \text { days after } \\
\text { seeding } \\
\text { propachlor - at flage state }\end{array}$ & $\begin{array}{r}990 \\
5280\end{array}$ & 32.56 & 80.4 & 274.8 \\
\hline $\begin{array}{l}\text { glyphosate - } 3 \text { days before leek } \\
\text { emergence } \\
\text { propachlor - at flag state }\end{array}$ & $\begin{array}{r}720 \\
5280 \\
\end{array}$ & 29.08 & 76.9 & 245.8 \\
\hline $\begin{array}{l}\text { propachlor }+ \text { glyphosate } \\
-3 \text { days before seed emergence } \\
\text { propachlor - at flag state }\end{array}$ & $\begin{array}{c}3840+720 \\
5280 \\
\end{array}$ & 30.75 & 78.1 & 240.6 \\
\hline hand weeded control & & 33.51 & 72.7 & 288.3 \\
\hline unweeded control & & 22.01 & 67.2 & 234.1 \\
\hline $\mathrm{LSD} P=0.05$ & & 5.06 & & 51.1 \\
\hline
\end{tabular}

\section{CONCLUSIONS}

1. The efficient method of weed control during leek seedlings raising was the use of pendimethalin at the rate of $990 \mathrm{~g} \cdot \mathrm{ha}^{-1}$ after seed sowing or mixture of propachlor $\left(3840 \mathrm{~g} \cdot \mathrm{ha}^{-1}\right)$ and glyphosate $\left(720 \mathrm{~g} \cdot \mathrm{ha}^{-1}\right)$ before seed emergence. 
2. Chemical weed control during seedling production did not adversely affect the quality of transplants and finally the yield of leeks. The only exception was glyphosate, which using was not so efficient in weed control resulting in lower quality of transplants and significant reduction of leek yield in comparison to the weed free control.

3. Supplementary use of propachlor at the flag stage had little effect on the level of weed infestation and did not affect on the quality of transplants and leek yield.

4. Heavy weed infestation of plants drastically decreased the quality of bare root transplants and diminished the marketable yield of leeks by $34.3 \%$.

\section{REFERENCES}

Adamczewska-Sowińska K., Kołota E. 2005. [The effects of seedling raising methods on yielding of leek grown for autumn harvest.] Zesz. Nauk. AR we Wrocławiu 515: 17-23. [in Polish with English summary]

Benjamin L.R. 1984. The relative importance of some different sources of plant weight variation in drilled and transplanted leeks. J. Agric. Sci. 103: 527-537.

Brewster J.L., Steckel J.R.A. 1989. Growth and development of leeks. AFRC Institute of Horticultural Research, Annual Report for 1988: 16-17.

Brewster J.L. 2008. Onions and other vegetable alliums. Cabi Head Office Nosworhy Way Wallingford.

Dobrzański A. 1998. Optymalne terminy odchwaszczania warzyw. Ochrona Roślin 12: 7-12. [in Polish]

Dobrzański A., Anyszka Z., Pałczyński J. 2002. [Contribution of Chenopodium album in weed infestation dependence on vegetable species and its response to some herbicides.] Pamiętnik Puławski - Materiały Konf. Z. 129: 141-149. [in Polish with English summary]

Fritz D., Stolz W., Venter F., Weichman J.M., Wonnenberger Ch. 1989. Gemüsebau. Verlag Eugen Ulmer. Stuttgart. [in German]

Grundy A.C., Knott C., Lutman P.J.W., Marshall,J., Sunderland K., Smith B., Fenlon J. 2003. The Impact of Herbicides on Weed Abundance and Biodiversity in Horticulture. Departament for Environment, Food and Rural Affairs.UK, project HH3403 sx Final Report (available at

http:||www.defra.gov.uk/science/projectdataDocumentLibray/HH34035X/, accessed 11 September 2007).

Krug H. Kling M.F. 1978. Ertrag und Qualität von Winterporree. Dtch. Gartenbau 19: 786-788. [in German]

Krug H. 1986. Gemüseproduktion. Paul Parey. Berlin und Hamburg. [in German]

Kołota E., Adamczewska-Sowińska K. 1995. The effect of seedling raising and planting methods in early production of leeks. Folia Hort. Ann. 7/1: 3-13.

Kołota E., Adamczewska-Sowińska K. 1996. Yield of early leeks in relation to agronomic variables. Folia Hort. Ann. 8/ 1: 19-28.

Le Bohec J., Erord P., Leitenturier J. 1993. Le poireau. Guide practique. CTIFL. Paris. [in French]

Synnevag G., Stubhang E. 1990. Oppalsmetoder og plantetall i purree. Gartneryrket. 80(17): 26-27. [in Dutch]

Maync A. 1990. Wege zum erfolgreichen Porreee-Anbau. Gemüse. 26(2): 74-78. [in German] 


\section{WPŁYW CHEMICZNEGO ODCHWASZCZANIA NA JAKOŚĆ ROZSADY \\ PRODUKOWANEJ W TUNELU FOLIOWYM ORAZ PLONOWANIE PORA}

\section{Streszczenie}

W latach 2006-2008 przeprowadzono badania nad oceną przydatności herbicydów pendimetalina (Stomp 330 EC), glifosat (Roundup 360 SL) oraz mieszaniny propachloru (Ramrod Flo 480 SC) i glifosatu (Roundup 360 SL) stosowanych przedwschodowo w czasie produkcji rozsady pora, a ponadto użycia propachloru po przejściu fazy zgiętego kolanka na tle przedwschodowo zastosowanych środków. Przedmiotem oceny był stan zachwaszczenia poletek, cechy jakościowe rozsady i uzyskany z niej plon pora.

Wyniki przeprowadzonych badań dowiodły, że skuteczną metodą niszczenia chwastów było posiewne zastosowanie preparatu pendimetalina w dawce $990 \mathrm{~g} \cdot \mathrm{ha}^{-1}$, bądź mieszaniny propachloru (3840 $\left.\mathrm{g} \cdot \mathrm{ha}^{-1}\right)$ i glifosatu $\left(720 \mathrm{~g} \cdot \mathrm{ha}^{-1}\right)$ przed wschodami pora. Uzupełniające zastosowanie propachloru po przejściu fazy zgiętego kolanka zwiększyło nieco efekt chwastobójczy herbicydów, nie miało jednak większego wpływu na jakość rozsady i plon roślin.

Chemiczne zwalczanie chwastów nie wpłynęło ujemnie na jakość rozsady i plon pora, z wyjątkiem herbicydu glifosat, którego mniejsza skuteczność chwastobójcza skutkowała obniżeniem cech jakościowych rozsady i plonu roślin. Silne zachwaszczenie utrzymujące się w kontroli nie odchwaszczanej spowodowało uzyskanie niskiej jakości rozsady i spadek plonu handlowego pora o $34,3 \%$. 